\title{
ASSESSMENT OF GROUNDWATER QUALITY AND WATER TABLE MAPPING OF BHAKTAPUR MUNICIPALITY
}

\author{
Razim Ganesh $^{1}$, Rebika Koju ${ }^{1}$, Raja Ram Prajapati ${ }^{2}$ \\ ${ }^{1}$ Department of Civil Engineering, Khwopa Engineering College, Libali-8, Bhaktapur, Nepal \\ ${ }^{2}$ Smartphones for Water (S4W) Nepal
}

\begin{abstract}
Water is necessary for all life on earth. Every living creature on the Earth depends on water for their survival; however the supply of water on Earth is limited. Groundwater, the important source of water supply to many people around the world, is accessed through stone spouts, springs, dug wells and infiltration galleries in and around Kathmandu Valley since ancient time. The extraction of groundwater in Kathmandu Valley is increasing day by day due to increase in population, haphazard urbanization and unplanned industrialization. Drinking water quality and quantity is one of the major issues which need to be taken seriously, since clean water and sanitation are human rights and essential to life. The present study aims to prepare water table map and groundwater quality map from unconfined aquifer of Bhaktapur Municipality. Geographic Information System (GIS) based groundwater table mapping for 472 samples were used. Inverse Distance Weighted (IDW) method was used for 86 samples for spatial interpolation of chemical indices. Surface maps are prepared for water quality parameters ( $\mathrm{pH}$, turbidity, conductivity, TDS, total hardness, iron, ammonia, nitrate, chloride, alkalinity and E-coli) in the GIS Software by interpolation between the available data. Water table elevation map shows that groundwater levels are shallow at wells located close to agricultural field. From the water quality mapping of the Bhaktapur Municipality, it is seen that the most of the water quality parameters are within the maximum permissible limit set by WHO and NDWQS. It is noted that quality of ground water in the study area exceeds Nepal drinking water quality standards on the basis of measured values of chloride, ammonia and nitrate in majority of wells. High concentration of chloride, ammonia and nitrate were found in most of water samples from the central part and in around the periphery of the municipality boundary, which may be due to infiltration of agricultural runoff and leaching of sewage pollutants.
\end{abstract}

Keywords: stone spouts, water table map, GIS, water quality, agricultural runoff.

\subsection{Introduction}

The availability of clean water is crucial for mankind's development in many important aspects and also an important economic and political issue in the future. Of all the water on the Earth, $98 \%$ is salt water, $1.6 \%$ is ice, $0.4 \%$ is groundwater and $0.004 \%$ is surface water (Kemira Kemwater, 2003). In light of this, it is clearly important that we look after existing water so that life on earth can continue to develop for the benefit of future generations.

\footnotetext{
*Corresponding author: Razim Ganesh

Department of Civil Engineering, Khwopa Engineering

College, Libali-8, Bhaktapur, Nepal

Email:razim13g@gmail.com
}

(Received: Nov 3, 2017 Accepted: May 8, 2018)
Groundwater is an important source of water supply in the Kathmandu Valley from ancient times though the means of accessing groundwater has been advancing towards mechanized extractions from traditional ones (e.g., stone spouts, springs, dug wells and infiltration galleries) used during ancient times. The scarcity of surface water and the increase in clear water demand have increased the usage of groundwater. Groundwater, the largest available source of fresh water, is also considered the best source of raw water since it is filtered naturally and has a low concentration of bacteria and other organic pollutants.

Extraction of groundwater has increased massively 
this last decade, and the trend is still uprising. The extraction of groundwater has increased from 2.3 Million-Litres-a-Day (MLD) in 1979 (Binnie and Partners, 1988) to 80 MLD in 2011 (personal communication with Mr. Hari P. Dhakal, Executive Director, Kathmandu Valley Water Supply Management Board). Nearly half of the total water supply from the government's authentic operator, Kathmandu Upatyaka Khanepani Limited (KUKL), during wet season and $60-70 \%$ during dry season is derived from groundwater sources (ICIMOD, 2007). The extensive use of the groundwater (beyond the rate of recharge) coupled with inadequate management of solid waste and wastewater from urban centers has increased the vulnerability of the groundwater system to (groundwater) resource depletion, quality degradation and land subsidence (Pandey et al., 2010).

In Kathmandu valley, $45 \%$ people depend on groundwater for drinking and domestic uses (MOPPW 2003). The groundwater in the valley at present is under threat because of heavy water withdrawal and increased pollution level. According to Stanley and Macdonald (1994), sustainable limit of groundwater withdrawal is approximately 26 million liters per day (mlpd) and shouldn't exceed $40 \mathrm{mlpd}$ (NWSC 1992). But total groundwater extracted in the Kathmandu valley at present is approximately 59 mlpd (Metcalf and Eddy 2000) which is much higher than permitted limit.

Drinking water quality and quantity has been one of the biggest concerns in water sector in the Kathmandu Valley, the biggest urban center in Nepal (Cresswell et al., 2001). The problems related to groundwater quality range from contamination from sewage line, septic failures, and open pit latrines, leaching from landfill sites, and direct disposal of domestic and industrial wastes to the surface water (Jha et al., 1997). Studies have shown that both the quantity and quality of groundwater in the Kathmandu Valley are in immense threat that needs immediate attention (Pradhanang et al., 2012). In this context, management of the valley's groundwater system including its source, quantity and quality are essential to ensure sustainable and equitable use of the precious resource (Johannessen, 2001). Similar is the case of Bhaktapur Municipality. The present study intends to prepare ground water table map and assess the quality of drinking water from the wells of unconfined aquifer of Bhaktapur Municipality area. The assessment of ground water quality status is important for socio-economic growth and development. The chemical parameters are the indicators directly related with the public health. Water quality evaluation for human consumption, agriculture and industrial activities have not been given attention especially in our context though chemical composition of water need regular monitoring before it is used for domestic or irrigation purpose. The importance of ground water quality in human health has recently attracted a great deal of interest as we know more than $80 \%$ of diseases are directly related to poor drinking water supply and unsanitary conditions. Water quality is affected by wide range of natural and human influences.

A complementary objective of this study was to demonstrate GIS capabilities in exploring the full value of ground water quality data through spatial analysis and visual display of geographic information.

\subsection{Study Area}

Bhaktapur Municipality, the historical and cultural city, is located at $27^{\circ} 36^{\prime}$ to $27^{\circ} 44^{\prime}$ North latitude and $85^{\circ} 21^{\prime}$ to $85^{\circ} 31^{\prime}$ East longitude. It lies at $12 \mathrm{~km}$ east of Kathmandu, the capital city of Nepal, and elevated at 1330 meter above sea level (J. Diwakar et al., 2008). The city is divided into 17 wards (10 now) and spreads over an area of 6.88 square kilometers. Mean daily temperatures range from $2{ }^{\circ} \mathrm{C}$ to $15{ }^{\circ} \mathrm{C}$ in winter and $19{ }^{\circ} \mathrm{C}$ to $27{ }^{\circ} \mathrm{C}$ in summer and annual rainfall is about $1500 \mathrm{~mm}$ (Thakur et al., 2015). People here depend upon wells, stone spouts, tube wells and piped water to fulfill their needs. According to recent census, the population of city is 81,748 residing in 17,639 households. $90 \%(15,998)$ of households use piped water (intermittent supply) as the main source of drinking water distributed by Nepal Drinking Water Corporation. The data show that the municipality consists of 87 stone spouts, 220 wells and 7207 piped lines (185 public stand posts) according to the research by Diwakar J. The study area is facing acute water shortage due to irregularities in water supply. Municipality is 
supplying water through tankers on regular basis to the study area so as to quench the thirst of the local people.

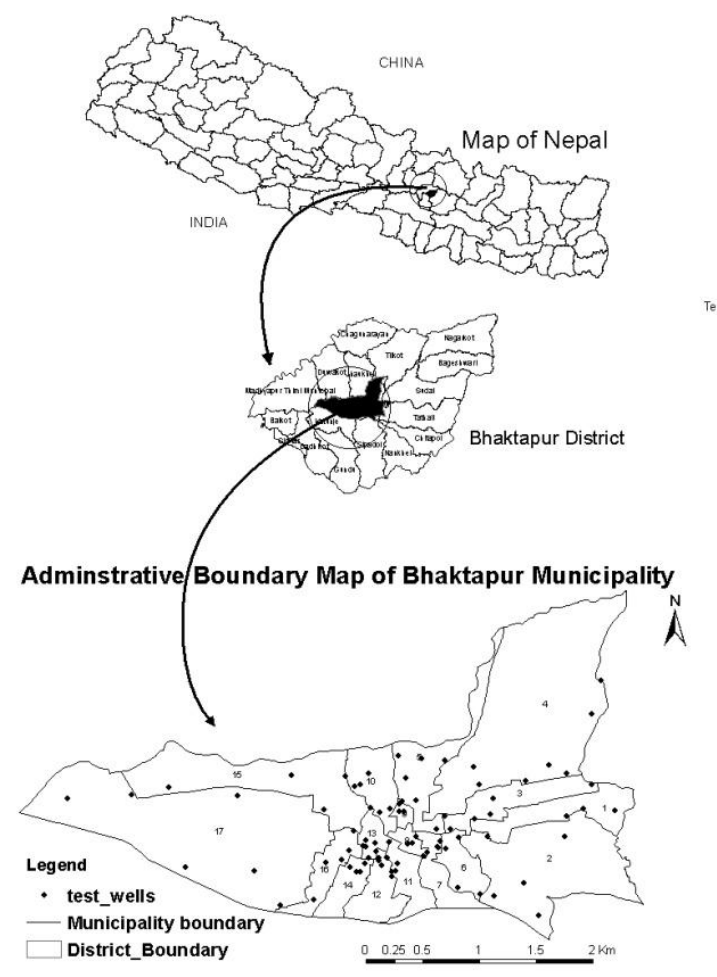

Fig 1 Map showing location of study area

\subsection{Materials and Methods}

The study was conducted in Bhaktapur Municipality area from December 2016 to February 2017. The study area has no adequate water supply. The partially and intermittent supplied water through pipe line is not totally free from contaminants. Altogether 472 wells were measured for the water table depth. Among them, 321 wells are private, and 151 are public. The 86 samples were collected manually from private and public wells which are being used for drinking and other domestic purposes. Water samples were collected in one litre bottle and tested in the laboratory of Khwopa Engineering College either on the same day or the next day using ENPHO test kit. The spatial co-ordinates of the sampling wells were measured on site using a hand held global positioning system (GPS) instrument GARMIN GPSMAP 62sc.

The geo-database was used to generate the spatial distribution maps of the chemical indices. The different locations of the sampling points were imported into GIS software through point layer. Data for selected parameters were linked to the sampling locations using geo-database creation function of GIS Software. The present study used the Inverse Distance Weighted (IDW) method for spatial interpolation of the chemical indices. The ground water quality parameters were analyzed for 86 representative samples collected randomly from the municipality. The surface maps were prepared for eleven water quality parameters $(\mathrm{pH}$, turbidity, conductivity, TDS, Total hardness, iron, ammonia, nitrate, chloride, alkalinity and E-coli) in the GIS software.

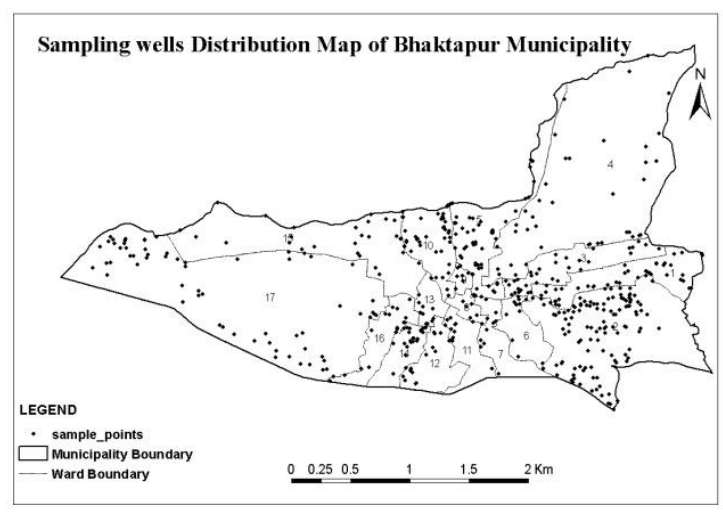

Fig. 2 Map showing sampling well locations

The water table depth, elevation mapping and water quality mapping were prepared using computer software application Geographic Information System (GIS). Water quality test was compared with the WHO standards and Nepal Drinking Water Quality Standards (NDWQS).

\subsection{Results and Discussions}

Interpretation of water table depth and water quality parameter helps to find out the current status of water level and the variations of physicochemical characteristics of groundwater (Mishra, P). The quality of groundwater gives the idea of suitability for drinking, domestic, agricultural and industrial purposes. Groundwater elevation map and quality maps are described below.

\subsection{Spatial Distribution of Water Table}

Water table map is a basic tool of hydro-geologic interpretation. It represents water level elevations that are measured in wells. 


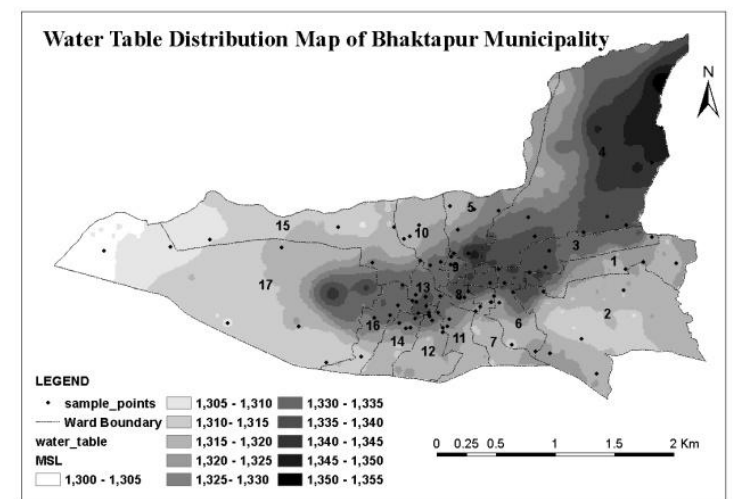

Fig.3 Spatial distribution of water table elevation in the study area

Figure 3 shows that the water table elevation is higher in the eastern part of the Municipality, whereas it is lower in the western part.

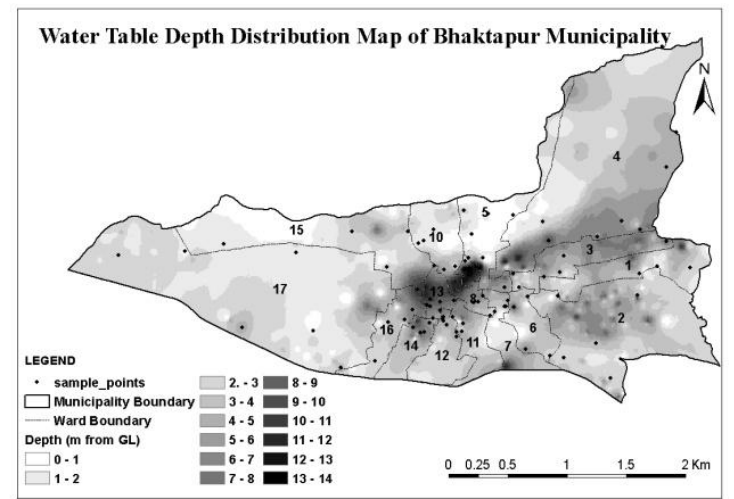

Fig.4 Spatial distribution of water table depth in the study area

From figure 4, it is seen that Ground water depth varies with well location from $0.1 \mathrm{~m}$ below ground level (mbgl) to $14.04 \mathrm{mbgl}$.

Table 1 Distribution of wells according to depth below ground level

\begin{tabular}{|c|c|}
\hline $\begin{array}{c}\text { Depth Below Ground } \\
\text { Level }\end{array}$ & Percentage of Wells \\
\hline Upto $4 \mathrm{mbgl}$ & $56.37 \%$ \\
\hline $4-8 \mathrm{mbgl}$ & $31.73 \%$ \\
\hline $8-12 \mathrm{mbgl}$ & $8.77 \%$ \\
\hline Greater than $12 \mathrm{mbgl}$ & $3.13 \%$ \\
\hline
\end{tabular}

The above table 1 shows that $56.37 \%$ of sample wells have water depth of $4 \mathrm{~m}$ below ground level, and $3.13 \%$ has water depth greater than $12 \mathrm{~m}$ below ground level. Water table depth is higher in the central part of Bhaktapur Municipality, whereas less water table depth is found around the periphery of the municipality.

\subsection{Spatial Distribution of Water Quality Parameters}

pH: The $\mathrm{pH}$ is one of the most important operational water quality parameter. The $\mathrm{pH}$ range in between 6.5 and 8.5 is the acceptable limit for drinking purpose according to WHO and NDWQS. The pH of water has no direct adverse effects on health; however, a lower value below 4 will produce sour taste and higher values hasten the scale formation.

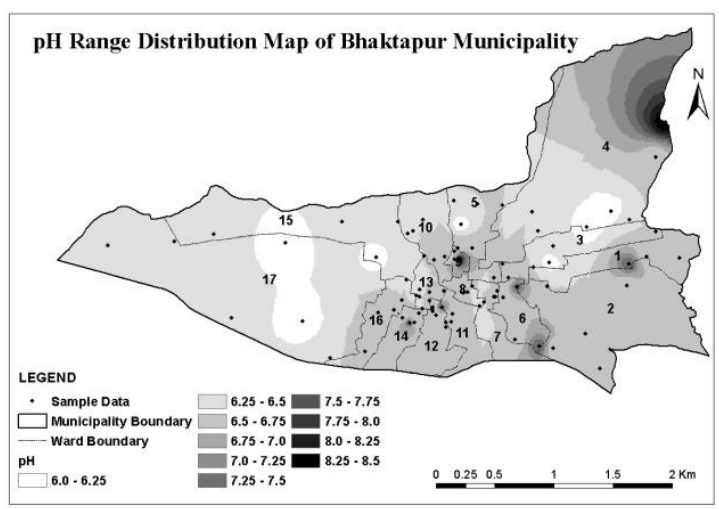

Fig.5 Spatial distribution of $\mathrm{pH}$ in the study area

From above figure 5, it is seen that most of the samples collected from public and private wells have the $\mathrm{pH}$ range in between 6.5 and 8.5 which is the acceptable limit for drinking purpose according to WHO and NDWQS. Only $8.13 \%$ samples are below 6.5 and $2.3 \%$ are above 8.5 which are not fit for drinking according to Nepal Drinking Water Quality Standards.

Turbidity: It is a measure of clarity of water which is caused by the presence of suspended particles. Water with high turbidity has offensive appearance, color and taste. Disinfection of water will be less effective due to the interference caused by the particles to detect microorganisms (J. Diwakar et al., 2008). Turbidity below $10 \mathrm{mg} / \mathrm{l}$ (NTU) is considered acceptance level for the drinking purpose according to WHO and NDWQS. 


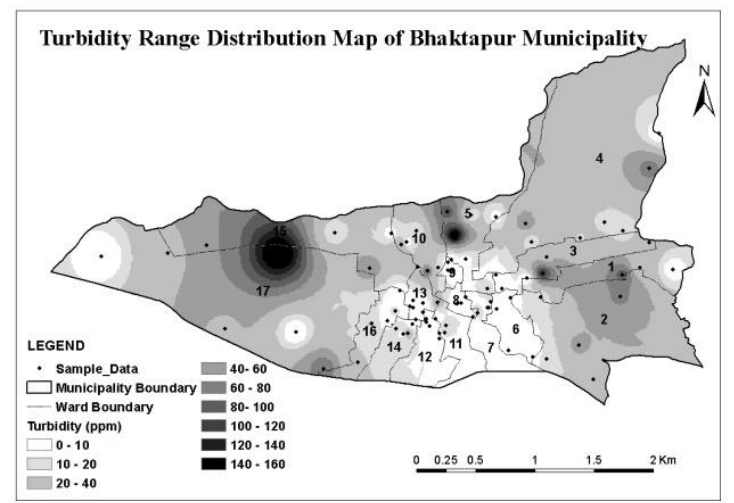

Fig. 6 Spatial distribution of Turbidity depth in the study area

The above turbidity range distribution map (fig 6) shows that $50 \%$ of sample wells have turbidity higher than the NDWQS and WHO standard. Around 13\% of sample wells have very high turbid water i.e. greater than $40 \mathrm{mg} / \mathrm{l}$.

Total Dissolved Solids (TDS): TDS are represented by the weight of residue left after heating water sample to dryness. Water may have large variety of salts such as chlorides, carbonates, bicarbonates, nitrates, phosphates and sulphates of calcium, magnesium, sodium, potassium, iron etc. The maximum permissible limit for TDS for drinking water is $1000 \mathrm{mg} / \mathrm{l}$. Higher value of TDS decreases palatability and may cause gastro intestinal irritations.

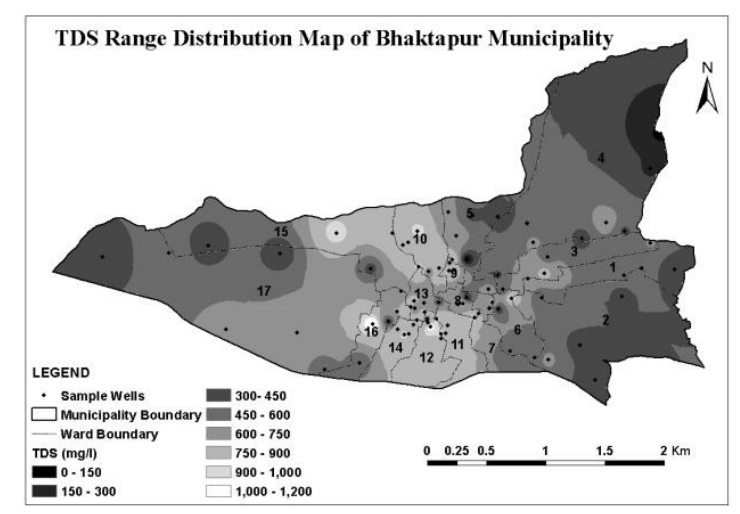

Fig. 7 Spatial distribution of TDS in the study area

Figure 7 shows that only $4.7 \%$ of sample wells have TDS beyond the limit range of WHO and NDWQS.

Conductivity: It is the measure of an ability to carry an electric current. As most of the salts in water are present in the ionic forms, which are capable to conduct current, conductivity is a good and rapid measure of the total dissolved solids.

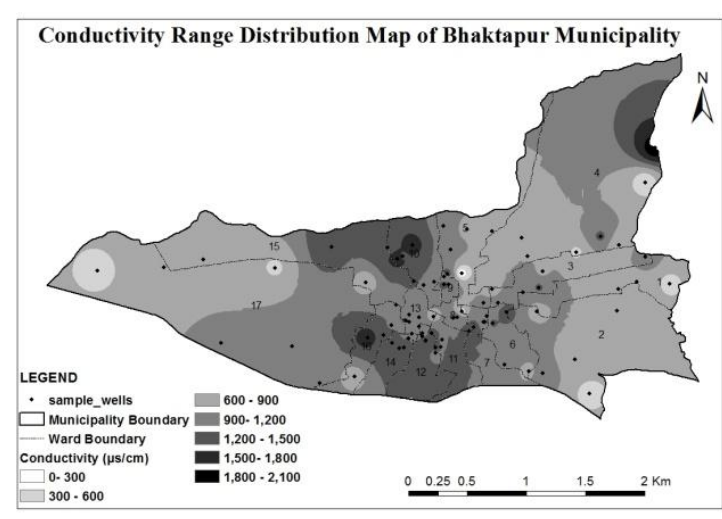

Fig. 8 Spatial distribution of Conductivity in the study area

The spatial distribution of conductivity range map shows that $7 \%$ of sample wells water is not within the acceptable limit set by WHO and NDWQS. Nepal drinking water quality standards has the limiting value of 1500 microsiemens per centimeter $(\mu \mathrm{s} / \mathrm{cm})$ of conductivity for the drinking purpose although it has no direct health effect. High conductivity value indicates addition of pollutants in it. Maximum value of conductivity was found $1980 \mu \mathrm{s} / \mathrm{cm}$ and the lowest value was $90 \mu \mathrm{s} / \mathrm{cm}$.

Total Hardness: It is the property of water that prevents formation of lather with soap. It is not regarded as pollution parameter as it does not harm the health in a major way.

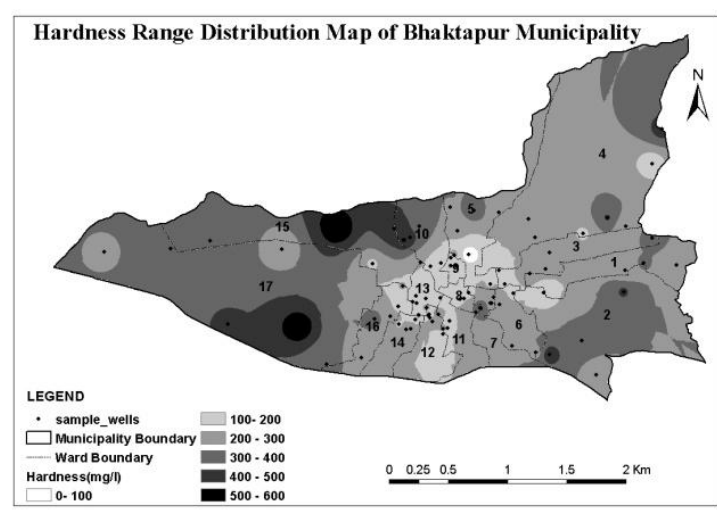

Fig.9 Spatial distribution of Total Hardness in the study area

The above figure shows that the central part of the municipality has total hardness in between 100- 200 $\mathrm{mg} / \mathrm{l}$ which is acceptable for the drinking purpose as per Nepal drinking water quality standards. Nearly 
$5 \%$ of sample wells show total hardness greater than $500 \mathrm{mg} / \mathrm{l}$ which is not fit for drinking according to WHO. The maximum value of hardness was found $600 \mathrm{mg} / \mathrm{l}$ and the minimum value of $16 \mathrm{mg} / \mathrm{l}$ was found in the study area according the laboratory test of the sample water.

\section{Iron:}

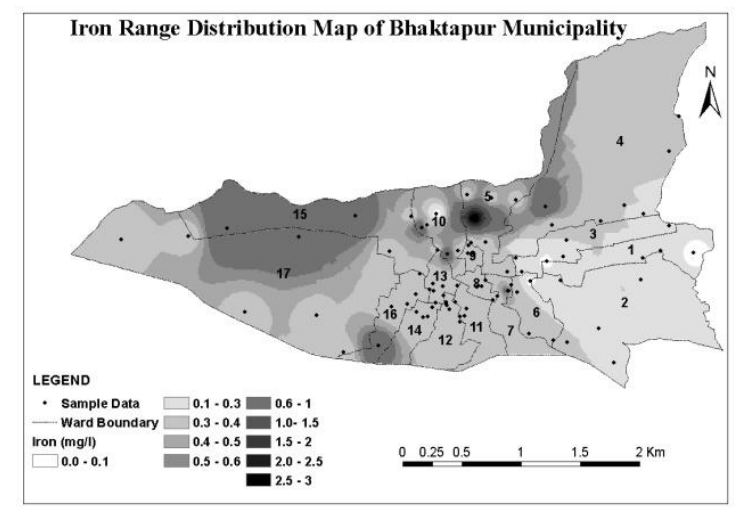

Fig.10 Spatial distribution of Iron in the study area

The IDW map presented in figure 10 shows that $88 \%$ of water samples have the iron content of $0.3 \mathrm{mg} / \mathrm{l}$, and around $12 \%$ of samples of water has iron content of $3 \mathrm{mg} / \mathrm{l}$ which is the maximum permissible value. South East area of the municipality has very low content of iron, whereas the Northern part has slightly higher concentration of iron though it is within the range of NDWQS.

\section{Chloride:}

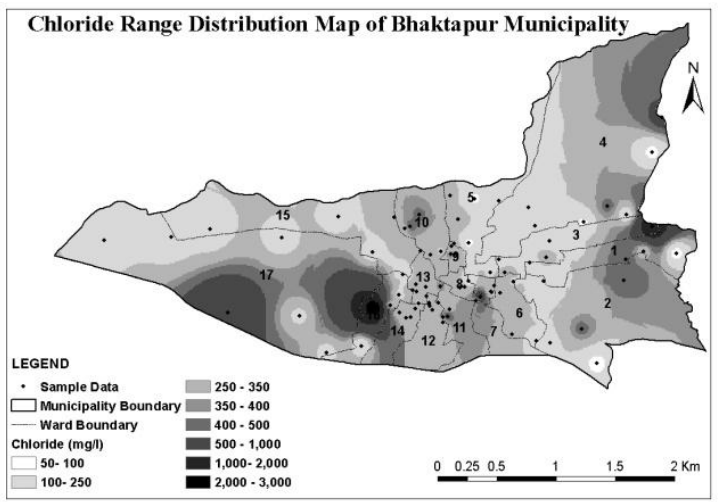

Fig.11 Spatial distribution of chloride in the study area

From above figure 11, it is observed that $57 \%$ of sample wells have chloride content more than 250 $\mathrm{mg} / \mathrm{l}$. Chloride content above $250 \mathrm{mg} / \mathrm{l}$ is beyond the acceptable range as per WHO and NDWQS. High concentration of chloride content is found in south west and eastern part of Bhaktapur Municipality which is the area of agriculture. High chloride content may affect in the soil property in a long run. If it is not controlled, it may lead to reduction of agricultural products.

\section{Ammonia:}

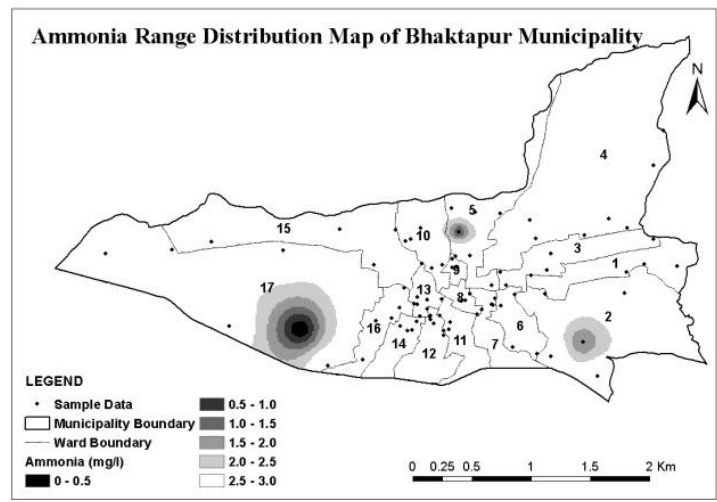

Fig.12 Spatial distribution of Ammonia in the study area

From figure 12, it is that $96.51 \%$ of sample wells have the ammonia content more than $1.5 \mathrm{mg} / \mathrm{l}$ which is beyond NDWQS. The possibility of high ammonia content is due to high use of fertilizers in the agricultural field and also due to the infiltration of sewage. Only few samples show the ammonia concentration within the range.

\section{Nitrate:}

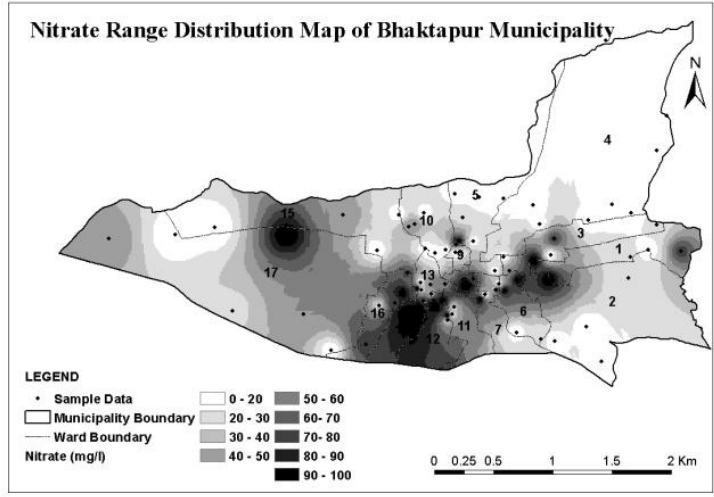

Fig.13 Spatial distribution of Nitrate in the study area

Spatial distribution map shown in figure 13 indicates that $55.81 \%$ of water samples have nitrate content more than $50 \mathrm{mg} / \mathrm{l}$ which is beyond permissible value. Water samples from the wells of the municipality periphery have shown low nitrate 
content but in the central part of municipality, it has the higher concentration of nitrate. The possible cause of higher value is the leaching of pollutants and higher uses of fertilizers.

\section{Alkalinity:}

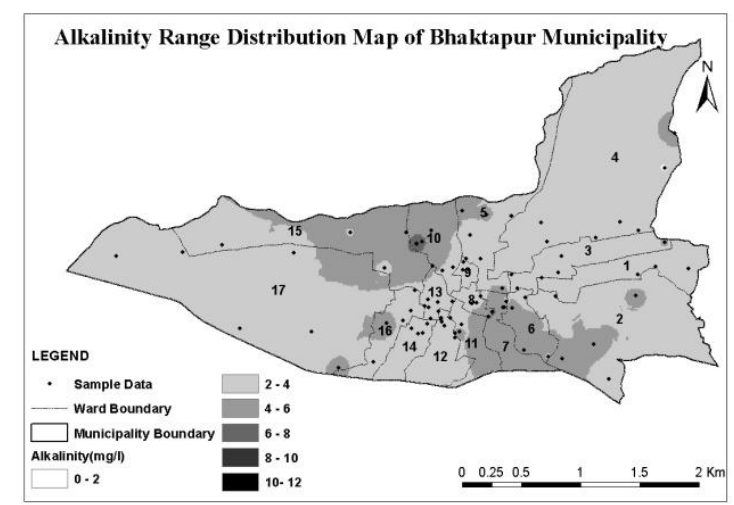

Fig.14 Spatial distribution of Alkalinity in the study area

Figure 14 shows that the majority of water samples have the alkalinity in between $2-4 \mathrm{mg} / \mathrm{l}$. The highest alkalinity range was found in between $4-6 \mathrm{mg} / \mathrm{l}$ which is not problematic for the agricultural use.

\section{E-Coli:}

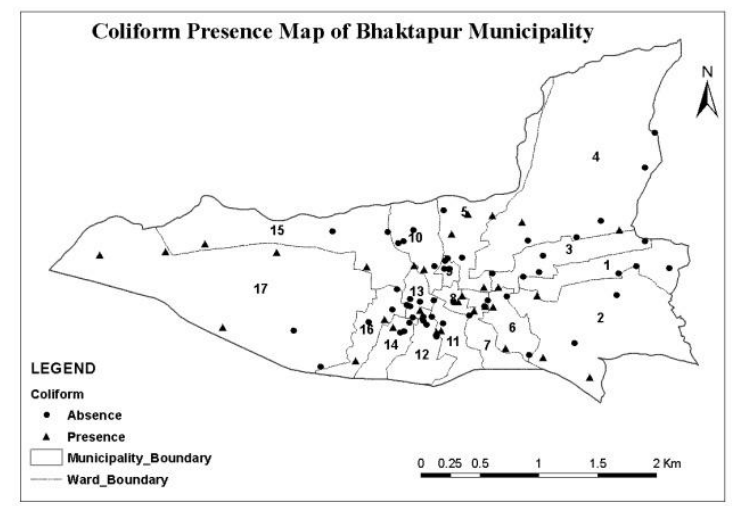

Fig.15 Spatial distribution of Coliform presence or absence in the study area

Figure 15 shows that $34.8 \%$ of water sample has Ecoli. The presence of E-coli is unfit for drinking. Nepal's drinking water quality standards say that there should not be presence of E-coli for drinking purpose.

\subsection{Conclusion}

The study provides the overview of current status of groundwater level of shallow aquifers and describes spatial distribution of groundwater level in Bhaktapur Municipality with GIS perspective. Groundwater data base, water table map and surface relief maps are developed which are useful for formulating sustainable groundwater use policies for local government.

Shallow groundwater levels are observed at wells located close to agricultural land. Till date, there are some agricultural fields in the periphery of the municipality in the northern and western part. Variations in ground water levels could be attributed to hydrogeology, land use and population density across the city. Another important factor affecting groundwater level is the number of wells and rate of extraction of groundwater.

The severity of drawdown in groundwater could be controlled through household level recharge and rainwater harvesting. The policy related with the effective groundwater management, zoning of urban areas and land use pattern, reforestation etc should be endorsed in order to control groundwater depletion. Policy level clarity regarding the abstraction and recharge of groundwater is needed so as to control the unrestricted business in groundwater overexploitation.

The water quality test shows $95.35 \%$ of water sample has the TDS value within the maximum permissible value and above $90 \%$ of water samples have $\mathrm{pH}$ and conductivity value within the acceptable range, however, $50 \%$ water samples are turbid than the permissible limit. The chemical properties like iron and total hardness have also no significant problems related with WHO and NDWQS guidelines. $88.37 \%$ of water samples have iron content within the acceptable limit and $95.35 \%$ of the samples have total hardness below $500 \mathrm{mg} / \mathrm{l}$. In the same way, it shows that $55.81 \%$ of water samples have nitrate concentration beyond the permissible limit and $96.51 \%$ have ammonia concentration above the acceptable range. The chloride concentration is above the permissible range for $56.98 \%$ of water samples. In the biological tests for E-coli, 34.88\% samples show presence of E-coli which means they are unfit for drinking purpose. 
An attempt has been made in this study to describe ground water quality of Bhaktapur Municipality and existing water table depth. The spatial distribution analysis of ground water quality indicated that many of the samples collected are within the range of Nepal Drinking Water Quality Standards except for the chloride, ammonia and nitrate. Bacteriological test shows the presence of E-coli in some of the sample wells which indicates the contamination from the domestic wastes. The high concentration of chloride, ammonia and nitrate dictates the infiltration and leaching of organic pollutants and fertilizers. Hence from this study, the water from the wells can be used for domestic and irrigation purposes only after certain level of treatment. In most of the samples, they are not clean enough to allow human consumption without any prior treatment. It is suggested to use filtration and other suitable treatment process for domestic uses.

It is essential to monitor ground water depletion and ground water quality extensively on a regular basis. Regular monitoring and analysis of groundwater quality and level help to prevent from further groundwater quality depletion and deterioration. Similarly, ground water recharge locations need to be identified.

Finally, it can be concluded that it is important to return water we borrow from the nature in such condition that it does not cause pollution.

\section{References}

[1] Binnie and Partners, 1988. Water supply for Kathmandu -Lalitpur from outside the valley pre-feasibility study, Final Report, Kathmandu, Nepal

[2] Cresswell, R. G., Bauld, J., Jacobson, G., Khadka, M. S., Jha, M. G., Shrestha, M. P., \& Regmi, S. (2001). A First Estimate of Ground Water Ages for the Deep Aquifer of the Kathmandu Basin, Nepal, Using the Radioisotope Chlorine-36. Groundwater, 39(3), 449-457.

[3] Diwakar, J., Yami, K. D., \& Prasai, T. (2008). Assessment of drinking water of Bhaktapur municipality area in pre-monsoon season. Scientific World, 6(6), 9498.

[4] Gillberg, L., Hansen, B., Karlsson, I., Enkel, A. N., \& Palsson, A. (2003). About water treatment. Kemira Kemwater.
[5] Jha, M. G., Khadka, M. S., Shrestha, M. P., Regmi, S., Bauld, J., \& Jacobson, G. (1995). The assessment of groundwater pollution in the Kathmandu Valley, Nepal. A Report on Joint Nepal-Australia Project, 1996.

[6] Metcalf and Eddy (2000). Urban water supply reforms in the Kathmandu Valley (ADB TA Number 2998-NEP). Completion report vol. I \& II - Executive summary, main report \& annex 1 through 7. Metcalf andEddy, Inc. with CEMAT Consultants Ltd.

[7] Mishra, P. Assessment of Groundwater Quality of Lalitpur District, Uttar Pradesh Using GIS Mapping.

[8] MOPPW (2003). Optimizing water use in Kathmandu valley report. HMG/Nepal: Ministry of Physical Planning and Works.

[9] NWSC (1992). Greater Kathmandu water supply project report. Nepal Water Supply Corporation.

[10] Pandey, V. P., Chapagain, S. K., \& Kazama, F. (2010). Evaluation of groundwater environment of Kathmandu Valley. Environmental Earth Sciences, 60(6), 1329-1342.

[11] Pradhanang, S. M., Shrestha, S. D., \&Steenhuis, T. S. (2012). Comprehensive review of groundwater research in the Kathmandu Valley, Nepal. S. Shrestha, D. Pradhananga, \& VP Panday, Kathmandu Valley Groundwater Outlook, 6-18.

[12] Rana, G., Murray, A. B., Maharjan, D. R., \& Thaku, A. K. (2007). Kathmandu valley environment outlook. International Centre for Integrated Mountain Development (ICIMOD).

[13] Stanley, I., \& Macdonald, M. (1994). Bagmati basin water management strategy and investment program report. Kathmandu: East Consult.

[14] Thakur, J. K., Diwakar, J., \& Singh, S. K. (2015). Hydrogeochemical evaluation of groundwater of Bhaktapur Municipality, Nepal. Environmental Earth Sciences, 74(6), 4973-4988. 